https://doi.org/10.15407/dopovidi2021.05.099

УДК 612.014.48:616-001.28

Е.А. Дьоміна, https://orcid.org/0000-0002-9313-8185

В.Г. Ніколаєв, https://orcid.org/0000-0003-3674-1612

Інститут експериментальної патології, онкології і радіобіології

ім. Р.Є. Кавецького НАН України, Київ

E-mail: edjomina@ukr.net

\title{
Радіобіологічні показники гострої променевої хвороби (чорнобильський досвід)
}

Представлено членом-кореспондентом НАН Украйни В.Г. Ніколаєвим

Досліджено особливості радіобіологічних показників залежно від ступеня гострої променевої хвороби до та після інтенсивної дезінтоксикаційної терапї 53 постраждалих внаслідок аварії на Чорнобильській АЕС, що лікувалися в клініщі Київського науково-дослідного рентгено-радіологічного та онкологічного інституту МОЗ України. Прояв первинних ушкоджень у хворих не завжди відповідав тяжкості променевої патології. Спостерігали, як правило, відтермінованість у розвитку лейко- $і$ лімфопеній порівняно з класичною формою променевої хвороби. Особливістю цитопеній крові був хвилеподібний характер їх перебігу. Відновлення показників крові в критичний момент було можливим лише за рахунок донорського кісткового мозку, що тимчасово брав на себе кровотворну функцію. Характерною рисою ультраструктурних змін у кістковому мозку внаслідок змішаного опромінення (зовнішнього $i$ за рахунок радіонуклідів) були дистрофія $i$ деструктивні зміни ендотелію синусів кісткового мозку. Всім хворим була проведена біологічна (иитогенетична) дозиметрія. Вперше запропоновано алгоритм визначення ступеня променевої хвороби на основі оптимального комплексу цитогенетичних показників радіаційного ураження Т-лімфоцитів із залученням моделі множинної лінійної регресії. Зіставлення даних цитогенетичної дозиметрії з клінічною симптоматикою дало можливість зробити об'єктивні висновки щодо диференціювання ступеня тяжкості променевої хвороби у межах строків, необхідних для виконання своєчасної дезінтоксикаційної терапії постраждалих. Чорнобильський досвід показав, що у випадку радіаційних інцидентів для оцінки тяжкості та прогнозу променевої патології, коректної біологічної дозиметрії доцільно проводити комплексне поглиблене радіобіологічне дослідження, яке включає гематологічне, цитогенетичне обстеження та аналіз кількісних і морфологічних показників кісткового мозку в зіставленні з клінічною симптоматикою опромінених осіб.

Ключові слова: Чорнобильська аварія, гостра променева хвороба, опромінені особи, радіобіологічні показники, цитопенії, біодозиметрія, підсадка кісткового мозку.

Променева хвороба (radiation disease) - певний комплекс проявів уражаючої дії іонізуючих випромінювань (IB) на організм людини. Різноманіття і тяжкість медико-біологічних iii проявів залежать від виду опромінення (загальне або місцеве, зовнішнє або від інкор-

Ци т у в ан н я: Дьоміна Е.А., Ніколаєв В.Г. Радіобіологічні показники гострої променевої хвороби (чорнобильський досвід). Допов. Наи. акад. наук Укр. 2021. № 5. С. 99-106. https://doi.org/10.15407/dopovidi 2021.05.099 
порованих радіоактивних речовин); часового (одноразове, повторне, пролонговане, хронічне) і просторового розподілу IB (рівномірне або нерівномірне), обсягу і локалізації опроміненої ділянки тіла [1].

Ступінь тяжкості гострої променевої хвороби (ГПХ) визначається величиною поглиненої дози IB: ГПХ I (легкого) ступеня (1-2 Гр); ГПХ II (середнього) ступеня (2-4 Гр); ГПХ III (важкого) ступеня (4-6 Гр); ГПX IV (украй важкого) ступеня (6-10 Гр); перехідні форми: кишкова (10-20 Гр); токсична (20-80 Гр) і нервова ГПХ (понад 80 Гр).

ГПХ, що розвивається при дозах понад 14 Гр, розцінюється як важка, але небезнадійна, тобто ще піддається лікуванню (курабельна). Однак ніякі методи сучасної терапії не зможуть запобігти летальному результату у разі опромінення людини в діапазоні доз, що викликають апоптоз не тільки радіочутливих, але й радіорезистентних клітин і тканин. Загибель великих масивів клітин призводить до важкої токсемії і виражених інкурабельних розладів гемодинаміки, які є безпосередніми причинами смерті постраждалих [2].

Чорнобильська катастрофа визначила особливу актуальність ранньої діагностики ступеня променевого ураження людини і ефективності лікування із залученням біологічних показників опромінення. У даній роботі обговоримо особливості одержаних нами результатів лабораторної діагностики та лікування ГПХ різного ступеня тяжкості у ліквідаторів наслідків аварії на Чорнобильській АЕС (ЧАЕС), оскільки вони внесли суттєві корективи в уявлення про дозозалежні ефекти в галузі радіобіології та радіаційної медицини. У перші дні, тижні після аварії на ЧАЕС зусилля медичних працівників були сконцентровані на стані постраждалих з діагнозом ГПХ I-IV ступенів, які перебували на промисловому майданчику АЕС в безпосередній близькості до епіцентру аварії. Через відсутність індивідуального дозиметричного контролю не було можливості в найближчі терміни, вже в умовах медсанчастини ЧАЕС провести медичне сортування постраждалих осіб залежно від величини поглиненої дози опромінення і скласти індивідуальний прогноз проявів променевої патології. Зазначене стало причиною того, що терміни звернення за медичною допомогою були розтягнуті і становили від кількох хвилин до кількох діб, а в окремих випадках навіть до 2-3 тижнів, коли вже почали проявлятися симптоми маніфестації ГПХ.

Мета роботи - провести ретроспективний аналіз і визначити особливості радіобіологічних показників залежно від тяжкості ГПХ до та після інтенсивної дезінтоксикаційної терапії постраждалих внаслідок аварії на ЧАЕС.

Матеріал і методи. Проведено ретроспективний аналіз і узагальнення результатів клініко-лабораторних обстежень 53 хворих на ГПХ I-III ступенів тяжкості, що лікувалися в клініці Київського науково-дослідного рентгено-радіологічного та онкологічного інституту (КНДРРОІ), нині Національний інститут раку МОЗ України. Обстеження хворих виконано в ранні та найближчі строки після аварії на ЧАЕС під керівництвом головного радіолога МОЗ України проф. Л.П. Кіндзельського. До арсеналу діагностичних методів у цілому входили динамічна радіометрія, дослідження клітинного та біохімічного складу крові, бактеріологічний контроль слизових оболонок; визначення кількісних, морфологічних та ультраструктурних показників кісткового мозку; прижиттєве дослідження інкорпорації радіонуклідів у пробах крові, кісткового мозку та слизових оболонках шлунка; імунологічні показники та стан імунологічного нагляду; біологічна (цитогенетична) дозиметрія на основі тест-системи лімфоцитів периферичної крові опромінених осіб. Одержані значення ра- 
діобіологічних показників, прояв яких був дозозалежним, дали змогу в короткий термін виконати верифікацію ступеня ГПХ для кожного пацієнта і скласти індивідуальні плани патогенетичної терапії.

Результати та обговорення. Прояв первинних ушкоджень у хворих на ГПХ не завжди відповідав тяжкості променевої патології. Так, первинна реакція показників крові за кількістю і часовими критеріями не повністю відповідала подальшому рівню порушень кровотворення. Спостерігали, як правило, відтермінованість у розвитку лейко- і лімфопеній порівняно з класичною формою ГПХ. Особливістю цитопеній крові був хвилеподібний характер їх перебігу. Тенденція до стабілізації показників білої крові намітилася через 45-60 днів після опромінення.

У хворих з ГПХ більш важкого (III) ступеня відзначали виражені зміни показників крові, обумовлені панцитопенією кісткового мозку. Відновлення показників крові в критичний момент було можливим лише за рахунок донорського кісткового мозку, що тимчасово брав на себе кровотворну функцію.

Таким чином, первинна реакція гематологічних показників крові за кількісними і часовими критеріями була не адекватною до наступного рівня порушення кровотворення. Більш пізніми були терміни розвитку агранулоцитозів, що пов’язано з інтенсивною терапією в перші дні перебування хворих у клініці й адекватною дезінкорпорацією радіонуклідів за методами ентеро- і гемосорбції. Саме методи сорбції стали важливим компонентом терапії постраждалих. Виправдало себе призначення ентеросорбентів з метою дезінтоксикації та виведення радіонуклідів з травного каналу [3]. У разі вираженої інтоксикації організму постраждалих за рахунок продуктів розпаду біологічних структур істотний ефект досягнутий за допомогою гемосорбційного очищення крові, корекції її білкового та електролітного складів. Незважаючи на відсутність специфічної спорідненості застосовуваних гемосорбентів з радіонуклідами сумарний вміст останніх після першого сеансу гемосорбції знижувався в середньому на 32,5 \%. Відзначалося зниження прояву вегето-судинної дистонії та дисциркуляторної енцефалопатії у хворих. Гемосорбція мала також імунокоригувальний ефект - знижувалася підвищена кількість В-лімфоцитів і нормалізувалося співвідношення Т-хелпери / Т-супресори. Комплексне лікування постраждалих з використанням гемосорбції сприяло позитивним зрушенням центральної і периферичної гемодинаміки. У результаті застосування ентеросорбції знижувалася ендогенна інтоксикація організму постраждалих [4-6].

Також встановлено, що IB пригнічує і руйнує кілерну систему організму хворих на ГПХ I-III ст. Протягом першого тижня госпіталізації природні кілери крові (ПКК) не визначалися. У хворих на ГПХ ІІІ ст. поодинокі ПКК реєструвалися лише через 3-4 тижні після опромінення, коли їм провели підсадку донорського кісткового мозку. Виявлено кореляцію між дозою опромінення, тяжкістю променевої патологї (ступінь ГПХ) та пригніченням цитогенетичного нагляду. Деструкція кілерної системи тим більш виражена, чим вища доза опромінення і, відповідно, важчий ступінь ГПХ.

Показники кісткового мозку за клітинним складом і морфологічним особливостям значно різнилися залежно від тяжкості променевої патології і термінів дослідження після опромінення. Характерною рисою ультраструктурних змін у кістковому мозку внаслідок змішаного опромінення (зовнішнього і за рахунок радіонуклідів) були дистрофія і де- 
структивні зміни ендотелію синусів кісткового мозку. Це проявлялося різкою вакуолізацією цитоплазми і порушенням цілісності плазматичних мембран клітин. У хворих на ГПХ III ст. відзначено збіднення паренхіми кісткового мозку форменими елементами крові.

Усім хворим на ГПХ була проведена біологічна дозиметрія, що грунтується на метафазному аналізі радіаційно-індукованих аберацій хромосом в “індикаторних” клітинах гемато-імунної системи (Т-лімфоцитах периферичної крові), з метою оцінки ступеня ГПХ під час цитогенетичного обстеження хворих після початку проведення курсу спеціальної терапії. Вперше було запропоновано алгоритм визначення ступеня ГПХ на основі оптимального комплексу цитогенетичних показників радіаційного ураження Т-лімфоцитів: частоти аберантних клітин, хромосомних фрагментів і аномальних моноцентриків із залученням моделі множинної лінійної регресії [7].

За результатами зіставлення даних цитогенетичної дозиметрії з клінічною симптоматикою зроблено об’єктивні висновки щодо диференціювання ступеня тяжкості променевої хвороби у межах строків, необхідних для виконання адекватної дезінтоксикаційної терапії постраждалих. Рекомендований спосіб забезпечив задовільний діагностичний рівень (відповідність первинно поставленим клініко-лабораторним діагнозам), тобто дав можливість уточнити або підтвердити ступінь ГПХ на тлі розпочатої інтенсивної дезінтоксикаційної терапії [8].

Реконвалесценти ГПХ у віддалені терміни страждають на поєднані хронічні захворювання внутрішніх органів і систем (від 5-7 до 10-12 діагнозів одночасно) [9]. У перші 5 років після аварії на ЧАЕС у цій групі постраждалих відзначалося різке зростання заворювань серцево-судинної, травної, нервової та інших систем організму. Через 25 років після аварії частка осіб із соматичними захворюваннями становила 85 і більше відсотків. У реконвалесцентів ГПХ у віддаленому періоді спостерігалися променеві катаракти, різні гематологічні синдроми, пов'язані зі зниженням вмісту зрілих клітин у периферійній крові. Вік померлих від злоякісних новоутворень та серцево-судинних захворювань був нижче середньої тривалості життя населення України [9]. Не було отримано достовірних статистичних даних кореляції частоти виникнення соматичної, неврологічної та іншої патології, включаючи пухлини, від ступеня тяжкості перенесеної ГПХ [10].

Дані експериментальних і клінічних досліджень, що отримані до Чорнобильської катастрофи, а також досвід застосування підсадок кісткового мозку онкологічним хворим, яким проводилася променева терапія, дозволили враховувати визначені закономірності для підсадки кісткового мозку хворим на ГПХ, які лікувалися в клініці КНДРРОІ. Розроблена модель найбільш відповідала синдрому аплазії кровотворення при гострому променевому ураженні. За мету лікувальної тактики ставилося тимчасове заміщення провалу кровотворення за рахунок донорського кісткового мозку для того, щоб за цей період власні поліпотентні гемопоетичні елементи мали змогу вийти на продукування елементів крові. Цей термін проходження через етапи диференціювання становив 12-15 діб для елементів мієлоїдного і еритроїдного рядів, протягом якого функціонує донорський кістковий мозок. На думку Л.П. Кіндзельского, “доураження решти елементів кісткового мозку недоцільно, тим більше що у хворих на ГПХ попередники кровотворення не є потенційно зміненими, як, наприклад, при лейкозі і пухлинах, а також немає сенсу прагнути до приживлення мієлотрансплантата на тривалий термін” [1]. 
Незважаючи на застосовану комплексну терапію, у частини хворих на ГПХ розвинувся виражений кістково-мозковий синдром. Показники клітинного складу крові і кісткового мозку були загрозливими для життя хворих. Використання донорської крові та їі компонентів у ряді випадків виявилися неефективними. У зв’язку з цим 11 пацієнтам була проведена підсадка кісткового мозку під керівництвом проф. Л.П. Кіндзельского. У 8 випадках був введений кріоконсервований, а в 3 - алогенний кістковий мозок безпосередньо від донорів. Вводилося від 11,9 $10^{9} /$ л до 10,0 $10^{9} /$ л мієлокаріоцитів. Підбір донорів кісткового мозку здійснювався спільно зі співробітниками Київського науково-дослідного інституту гематології та переливання крові МОЗ України з урахуванням гістосумісності за системою HLA, ABO, Rh, MN. Під час обстеження найближчих родичів - батько, мати, брати, сестри - виявилося, що в жодному з 11 випадків кістковий мозок не був придатним для трансплантації за груповими ознаками або за локусами системи HLA. Забір кісткового мозку проводився в основному з тазових кісток методом аспірації. Аспірований шприцами кістковий мозок поміщався у флакон з консервантом. 3 ретельно змішаного вмісту флакона бралися проби для визначення кількості мієлокаріоцитів. Підсадка проводилася також внутрішньокістково в клубову або одночасно в клубову й стернальну кістки. Вводилося від $6 \cdot 10^{9} /$ л до $9 \cdot 10^{9} /$ л мієлокаріоцитів в об'ємі 120-200 мл.

Ці операції були проведені через 3-6 тижнів після опромінення. Така відстрочка в підсадці обумовлена низкою факторів. По-перше, елементи, які диференціюються, що залишилися в кістковому мозку, продовжували продукувати клітини крові. По-друге, інкорпоровані радіонукліди могли руйнувати не тільки власні, а й трансплантовані мієлокаріоцити. Тому доцільніше підсаджувати кістковий мозок після проведених заходів, що були спрямовані на дезінтоксикацію і розпад короткоживучих ізотопів. За час функціонування донорського кісткового мозку власна відновлювальна кровотворна тканина продукує клітини крові, тобто підсадка кісткового мозку розглядається як тимчасова замісна терапія.

У всіх хворих, яким у клініці КНДРРОІ була проведена підсадка кісткового мозку, через 3-6 тижнів спостерігалося відновлення клітинного складу крові. У жодного з 11 хворих після підсадки кісткового мозку не виявлено ані ранніх, ані пізніх ускладнень. Усі хворі на ГПХ, що лікувалися в клініці КНДРРОІ, були виписані в задовільному стані і залишилися живі. У різні для кожного з них терміни було констатовано відновлення власного кровотворення.

Інша ситуація склалася з хворими на ГПХ (27 осіб з ГПХ III-IV ступеня і 1 особа з ГПХ II ступеня), які лікувалися водночас в 1986 р. у спеціалізованій клініці № 6 Інституту біофізики (Москва). Після трансплантації кісткового мозку спочатку у них спостерігалося більшою чи меншою мірою відновлення власної кровотворної тканини. Однак постраждалі загинули раніше, ніж настала продукція зрілих елементів крові, від несумісних з життям гострих променевих уражень шкіри, кишечника, радіаційного пневмоніту, змішаних бактеріально-вірусних інфекцій, гострої вторинної хвороби (“трансплантат проти хазяїна”). Також були зареєстровані випадки реакції відторгнення трансплантата (хвороба “хазяїн проти трансплантата”) [11].

Таким чином, підсадки кісткового мозку, ініційовані та здійснені під керівництвом проф. Л.П. Кіндзельского в клініці КНДРРОІ, виявилися високоефективним засобом лікування хворих з діагнозом ГПХ з пошкодженням кровотворної тканини, що загрожують життю, і 
цитопеніями крові. Підсадкою кісткового мозку досягнуто мети тимчасового заміщення кровотворної функції, тобто така операція використана як тимчасова замісна терапія.

Крім того, відзначимо, що в осіб, які перенесли ГПХ різного ступеня тяжкості, в післяаварійний період виявлено стійкі зміни окисного гомеостазу: підвищення вмісту первинних і вторинних продуктів пероксидного окиснення ліпідів, зниження активності ферментів антиоксидантного захисту. Найбільше накопичення первинних продуктів пероксидного окиснення ліпідів реєструвалося під час обстеження ліквідаторів через 8-9 років після аваpiï [12]. Згідно з даними [10], протягом усього життя у ліквідаторів, які перенесли ГПХ, зберігається високий ризик розвитку пізніх променевих ефектів, у зв'язку з чим необхідний постійний моніторинг стану їх здоров’я. Тривале спостереження за представниками цієї групи постраждалих показало, що серцево-судинні та онкологічні захворювання домінують серед інших причин смертності.

Висновки. У випадках радіаційних інцидентів для оцінки тяжкості та прогнозу променевої патології, удосконалення біологічної дозиметрії доцільно проводити комплексне поглиблене радіобіологічне обстеження опромінених осіб, яке включає: гематологічне (аналіз показників периферичної крові) і цитогенетичне (аналіз рівня та спектра радіаційно-індукованих аберацій хромосом у Т-лімфоцитах крові), а також аналіз кількісних і морфологічних показників кісткового мозку в зіставленні з клінічними променевими проявами. Чорнобильський досвід діагностики та лікування постраждалих з ГПХ слід неодмінно враховувати для підвищення готовності надання кваліфікованої допомоги населенню у разі масових променевих уражень.

\section{ЦИТОВАНА ЛІТЕРАТУРА}

1. Киндзельский Л.П., Зверкова А.С., Сивкович С.А. и др. Острая лучевая болезнь в условиях Чернобыльской катастрофы. Киев: Телеоптик, 2002. 224 с.

2. Протасова Т.Г. Патологическая картина ОЛБ в условиях современного лечения. Мед. радиология $u$ радиаи. безопасность. 1999. 44, № 5. С. 27-32.

3. Пинчук Л.Б. Особенности целесообразности усиленной детоксикационной терапии при гипоплазии кроветворения. Гематол. и перелив. крови. 1987. № 12. С. 111-115.

4. Nikolaev V.G., Pinchuk L.B., Umansky M.A. et al. Early experimental studies on hemoperfusion as a treatment modality for acute radiation disease. J. Artif. Organs. 1993. 17, № 5. P. 362-365.

5. Zakharash M.P., Pinchuk L.B., Ivanova N.V. et al. Adsorptive treatment of radiation and postradiation syndroms: update and prospects. Sorption methods and technologies in settlement of ecological and endoecological problems of the Chernobyl accident. Program and abstracts. 2000. P. 75.

6. Захараш М.П., Николаев В.Г., Иванова Н.В., Гурина Н.М. Сорбционная терапия в коррекции постлучевых поражений. Фармакол. вісн. 1997. № 3. С. 44-47.

7. Дьоміна Е.А., Клюшин Д.А., Кіндзельський Л.П., Петунін Ю.І. Цитогенетична оцінка ступеня гострої променевої хвороби. Методичні рекомендації. Київ: МОЗ України, 1999. 16 с.

8. Дёмина Э.А., Петунин Ю.И., Клюшин Д.А. Применение теста абераций хромосом для ретроспективной оценки степени острой лучевой болезни. Лабораторная диагностика. 1998. № 3. С. 24-27.

9. 25 лет Чернобыльской катастрофы. Безопасность будущего. Национальный доклад Украины. Киев: KiM, 2011.368 c.

10. Білий Д.О., Сушко В.О., Коваленко О.М., Базика Д.А. Стан здоров’я осіб, які перенесли гостру променеву хворобу внаслідок аварії на Чорнобильській АЕС. Радіологічні та медичні наслідки Чорнобильської катастрофи. 30 років потому: Матеріали Міжнар. наук. конф. (Київ, 18-19 квітня 2016). Київ, 2016. C. 182. 
11. Чернобыльская катастрофа: Барьяхтар В. Г. (ред.). Киев: Наук. думка, 1995. 560 с.

12. Коваленко А.Н., Коваленко В.В. Системные радиационные синдромы. Николаев: НГгУ им. Петра Могилы, 2008. 248 с.

Надійшло до редакції 28.06.2021

\section{REFERENCES}

1. Kyndzelskyi, L. P., Zverkova, A. S., Syvkovych, S. A. et al. (2002). Acute radiation disease in the conditions of the Chernobyl disaster. Kyiv: Teleoptic (in Russian).

2. Protasova, T. H. (1999). Pathological picture of acute radiation disease in the conditions of modern treatment. Med. radyologyia i radyats. bezopasnost, 44, No. 5, pp. 27-32 (in Russian).

3. Pynchuk, L. B. (1987). Features of the expediency of enhanced detoxification therapy for hypoplasia of blood formation. Hematol. i perelyv. krovy, No. 12, pp. 111-115 (in Russian).

4. Nikolaev, V. G., Pinchuk, L. B., Umansky, M. A. et al. (1993). Early experimental studies on hemoperfusion as a treatment modality for acute radiation disease. J. Artif. Organs., 17, No. 5, pp. 362-365.

5. Zakharash, M. P., Pinchuk, L. B., Ivanova, N. V. et al. (2000). Adsorptive treatment of radiation and postradiation syndroms: update and prospects. In: Sorption methods and technologies in settlement of ecological and endoecological problems of the Chernobyl accident. Program and abstracts, p. 75.

6. Zakharash, M. P., Nikolaev, V. H., Ivanova, N. V. \& Huryna, N. M. (1997). Sorption terapy in the correction of post-radiation injuries. Farmakolohichnyi visnyk, No. 3, pp. 44-47 (in Russian).

7. Domina, E. A., Kliushyn, D. A., Kindzelskyi, L. P. \& Petunin, Yu. I. (1999). Cytogenetic assessment of the degree of acute radiation sickness. Guidelines. Kyiv: MOZ Ukrainy (in Ukrainian).

8. Domina, E. A., Petunyn, Yu. I. \& Kliushyn, D. A. (1998). Application of the chromosome aberration test for retrospective assessment of the degree of acute radiation sickness. Laboratornaia dyahnostyka, No. 3, pp. 24-27 (in Russian).

9. 25 years of the Chernobyl disaster. Security for the future. National report of Ukraine (2011). Kyiv: KiM.

10. Bilyi, D. O., Sushko, V. O., Kovalenko, O. M. \& Bazyka, D. A. (2016, April). The state of health of people who suffered from acute radiation sickness as a result of the Chernobyl accident. Proceedings of the International Scientific Conference Radiological and medical consequences of the Chernobyl disaster. 30 years later (p. 182), Kyiv (in Ukrainian).

11. Bariakhtar, V. H. (Ed.). (1995). Chernobyl disaster. Kyiv: Naukova Dumka (in Russian).

12. Kovalenko, A. N. \& Kovalenko, V. V. (2008). Systemic radiation syndromes. Nykolaev: NHHU im. Petra Mohyly (in Russian).

Received 28.06.2021

E.A. Domina, https://orcid.org/0000-0002-9313-8185

V.G. Nikolaev, https://orcid.org/0000-0003-3674-1612

R.E. Kavetsky Institute of Experimental Pathology, Oncology and Radiobiology

of the NAS of Ukraine, Kyiv

E-mail: edjomina@ukr.net

\section{RADIOLOGICAL INDICATORS OF ACUTE RADIATION DISEASE (CHERNOBYL EXPERIENCE)}

We have studied the specificities of radiological parameters depending on the degree of acute radiation disease before and after intensive detoxification therapy of 53 victims of the Chernobyl accident. They were treated in the clinic of the Kyiv Research X-ray Radiology and Oncology Institute of the Ministry of Health of Ukraine. The manifestation of primary injuries in patients did not always correspond to the severity of radiation pathology. In general, we have observed the delayed development of leukopenia and lymphopenia was observed as compared to the classical form of radiation disease. The specificity of blood cytopenia was the wavy nature of its course. Restoration of blood parameters at a critical moment was possible only due to the donor bone marrow, which temporarily assumed haematopoietic function. A characteristic feature of ultrastructural changes in the bone 
marrow under mixed irradiation (external and due to radionuclides) were dystrophy and destructive changes in the endothelium of the sinuses of the bone marrow. All patients underwent biological (cytogenetic) dosimetry. For the first time, an algorithm for determining the degree of radiation disease based on the optimal set of cytogenetic indicators of radiation damage of T-lymphocytes with the involvement of a model of multiple linear regression was proposed. A comparison of cytogenetic dosimetry data with clinical symptoms allowed us to draw objective conclusions about the differentiation of the severity of radiation disease within the time required for timely detoxification therapy of victims. The Chernobyl experience showed the following. In case of radiation incidents, it is advisable to conduct a comprehensive radiological study, which includes haematological and cytogenetic examination, as well as an analysis of quantitative and morphological parameters of the bone marrow in comparison with the clinical symptoms of irradiated persons.

Keywords: Chernobyl accident, acute radiation disease, irradiated persons, radiological indicators, cytopenia, biodosimetry, bone marrow transplantation. 